\title{
A PROGRESS REPORT ON THE EARTHQUAKE HAZARD CENTRE
}

\author{
Andrew Charleson ${ }^{1}$
}

\begin{abstract}
SUMMARY
This report outlines the current progress of the Earthquake Hazard Centre, a seismic hazard reduction resource centre for developing Commonwealth countries which was established some two and a half years ago. The Centre aims to encourage developing countries to adopt basic building seismic design and construction practices that are taken for granted in more developed countries. After backgrounding the context in which the Centre was initiated, the report describes the Centre's networks and its primary publication, the quarterly newsletter. A financial report is included, and finally, possibilities for future development are suggested.
\end{abstract}

\subsection{INTRODUCTION}

Origins:

The idea to form the Earthquake Hazard Centre emerged during the Workshop on Seismic Hazard Mitigation of Non-engineered Structures. Held at the National Geophysics Research Institute, Hyderabad, India in June 1996, the workshop [1] was sponsored by the Commonwealth Science Council. During the workshop the large gap between the so called developed and developing countries in terms of their knowledge and practice of earthquake hazard reduction became quite obvious. It also became apparent that significant hazard reduction can be achieved only by implementing existing techniques already proven in developed countries. The challenge to disseminate technologically appropriate information and to encourage appropriate indigenous research efforts could not be dismissed.

At the conclusion of the workshop, during a closing panel discussion, workshop participants endorsed a proposal to establish an earthquake hazard reduction resource centre based at Victoria University of Wellington. It was agreed that the objectives of the Centre would be to gather outcomes of appropriate earthquake hazard research, monitor on-going international research and hazard reduction programs, and to disseminate any information particularly relevant to the needs of developing countries. A quarterly newsletter was the principal envisaged outcome. At the time of the proposal no such Centre with an international focus on the earthquake engineering needs of developing countries was known. A subsequent extensive Internet and literature search has not revealed any others, although several organizations cover a broader range of natural hazards.
In April 1997, the Commonwealth Science Council approved financial support up to the year 2000 . Work began soon after to establish the Centre, now named the Earthquake Hazard Centre (EHC)

\subsection{PROGRESS TO DATE}

Developing networks:

Two levels of networking and mailing lists have been developed. The first mailing list consists of researchers and research institutions whose activities are immediately relevant to developing countries. Through it, the Centre interacts with 88 contacts in 39 countries. The second list of "recipients" comprises individuals and organisations who have been selected to receive disseminated information. Appendix 1 shows the numbers of newsletters mailed to each country. Note that the large numbers of Indian mailings is a result of collaboration between the EHC and the Indian Society for Earthquake Technology (ISET). In December 1998 the EHC Director negotiated that ISET will print the newsletter and mail it to its $500+$ active members in return for a modest annual grant to cover printing costs. As well as the printed newsletter, the Centre has an Email list of 100 people and institutions around the world. In an effort to minimize postal charges these contacts are advised by email each time a new issue is posted on the EHC web site [3]. Almost all on this list are from nonCommonwealth countries. Each month several people request to be added these lists.

Developing Commonwealth countries listed in Appendix 1 can expect maximum Modified Mercalli intensity of VI or greater

1.

${ }^{1}$ Director, Earthquake Hazard Centre, Victoria University of Wellington. 
shaking with an exceedance probability of $20 \%$ in 50 years, equivalent to a 250 year return period. Typically, the following organisations are on the mailing list: government housing, building or construction departments; local bodies; universities and polytechnics with engineering or architecture faculties; consulting engineers; architectural and civil engineering professional bodies.

During the Indian visit mentioned above, the Director formed strategic links with many Indian earthquake engineers. This contact was facilitated by the lectures and conference paper at Roorkee and Kanpur that were presented. More detailed information on the trip is available [2].

The number of recipients, and their geographic distribution, is capable of considerable development. Many countries are poorly covered, but an expansion of the mailing list is dependent upon increased funding.

\section{Newsletter:}

The Newsletter, published quarterly both in printed form and on the Internet, is the main vehicle for dissemination of information. The editorial objectives are to:

- disseminate earthquake engineering knowledge relevant to developing countries;

- establish new or improve existing seismic design and construction practices;

- $\quad$ promote good seismic damage reduction practices to the readership:

- $\quad$ provide a forum for contributions and discussion from developing countries, and to

- encourage networking of ideas and research outcomes.

The academic level of content is aimed at a structural engineer or architect in a provincial city within a developing country. The content of a typical newsletter includes an editorial, book reviews, summaries of relevant papers and a section on principles of earthquake resistance for buildings. Some researchers and practitioners from developing countries have contributed material themselves. The Director continues to scan conference proceedings, journals and similar sources for relevant material for publication in the Newsletter.

To date, all feedback on the newsletter has been very positive. One Indian academic mentioned how he uses material from the Newsletters in his classes. A suggestion from another lecturer to incorporate a section 'new publications' has been implemented.

In July 1998 the EHC Partnering Scheme was announced. Recipients were invited to send structural documentation to the Centre for a limited-in-scope but free seismic design review. Unfortunately the offer was not taken up but it might be promoted again when links with local consultants are stronger

Web site:

Mr. David Eyles, from Victoria University of Wellington's School of Architecture, has designed and continues to maintain the site. Each newsletter, when completed, is added to the site. The site, which is linked to several other relevant organisations attracts a reasonable amount of attention. Web server statistics indicate that at present the site receives approximately 350 visits per month

Resourcing:

The EHC is funded by the Commonwealth Science Council of the Commonwealth Secretariat. An annual grant of GBP 4000 covers costs such as printing and mailing, payment of one parttime research assistant (one day per week), and an expenses contribution to the School of Architecture, Victoria University of Wellington.

At present there is no external professional oversight of the Centre's activities, nor is it affiliated to any other organisation, however the Director reports every quarter and sends copies of the newsletter to members of the Management Committee of the NZ Society for Earthquake Engineering. Reports are also sent to the Commonwealth Science Council.

\subsection{FINANCIAL REPORT}

A summary of annual expenditure is show in the Table below.

\begin{tabular}{|c|c|c|}
\hline Expenditure items & $\begin{array}{l}\text { Annual } \\
\text { expenditure } \\
\text { NZ\$ }\end{array}$ & Notes \\
\hline $\begin{array}{l}\text { Research } \\
\text { Assistants' wages }\end{array}$ & 4500 & $\begin{array}{l}\text { A student one } \\
\text { day per week }\end{array}$ \\
\hline Professional fees & 220 & Proof reading \\
\hline Books/journals & 400 & \\
\hline Consumables & 100 & \\
\hline Photocopier & 200 & \\
\hline Postage & 1400 & 4 newsletters \\
\hline Printing & 1000 & 4 newsletters \\
\hline Faxes/phone & 130 & \\
\hline $\begin{array}{l}\text { School of } \\
\text { Architecture }\end{array}$ & 5,000 & Two annual grants \\
\hline ISET & 550 & Indian newsletters \\
\hline TOTAL & 13,500 & \\
\hline
\end{tabular}

Full details of expenditure are available in the statement of accounts compiled by Victoria University's financial section, which is signed by the School of Architecture's Financial Manager. The reported expenditure is offset against the annual grant from the Commonwealth Science Council of \$NZ13,500. An analysis of the accounts indicates that the Centre is just living within the annual grant from the CSC. No expansion of activities is possible unless an increase in funding is obtained. 


\subsection{THE FUTURE}

Although the Centre is over two years old there are still many areas in which it can develop. At present it focuses on Commonwealth countries. A natural extension would see it broaden its scope to include all developing countries. To a limited extent that occurs now, with the Newsletter published on the Internet. More effective dissemination however would require larger mail-outs. Additional funding must first be acquired, and then consolidated, given that the Commonwealth Science Council funding ceases in 2000. Possibilities for raising additional funds, for example by advertising, need to be considered. Some consulting firms may wish to purchase Newsletters for distribution by themselves or through the Centre. In the future there may be opportunities for contract research and to run earthquake engineering training courses. New Zealand and international aid agencies such as the ADB and DMF (Disaster Management Facility, World Bank have been approached for support, but so far without success.

\subsection{CONCLUSION}

Since its inception two and a half years ago the Earthquake Hazard Centre has provided a unique source of appropriate seismic hazard reduction information to developing countries, with the aim of improving the science and practice of seismic hazard reduction in the context of building design and construction. New sources of funding must be obtained to ensure the continuing contribution of the Centre.

\subsection{REFERENCES}

1. Charleson, A. W. and Sharpe, R. D. Workshop on Seismic Hazard Mitigation of Non-engineered Structures, the National Geophysics Research Institute, Hyderabad, India, 2 - 8 June 1996, Bulletin of the New Zealand Society for Earthquake Engineering, Vol. 29, No. 3, September 1996, p. 209.

2. Charleson A. W. Report to the Commonwealth Science Council on a visit to India by A.W. Charleson, Director, Earthquake Hazard Centre, December 1998.

3. EHC web site is at http://www.ehc.arch.vuw.ac.nz

Appendix 1: Number of newsletter recipients per country

\begin{tabular}{|l|l|l|l|}
\hline Country & No. & Country & No. \\
\hline Antigua and Barbados & 2 & Nepal & 3 \\
\hline Australia & 2 & Nauru & 1 \\
\hline Bangladesh & 16 & New Zealand & 5 \\
\hline Barbados & 2 & Nicaragua & 1 \\
\hline
\end{tabular}

\begin{tabular}{|c|c|c|c|}
\hline Belize & 2 & Pakistan & 19 \\
\hline Botswana & 2 & Papua New Guinea & 12 \\
\hline Brunei & 13 & Philippines & 1 \\
\hline Costa Rica & 1 & South Africa & 31 \\
\hline Cameroon & 3 & Solomon Islands & 5 \\
\hline Central Africa & 1 & Sri lanka & 1 \\
\hline Cypress & 4 & $\begin{array}{l}\text { St. Christopher \& } \\
\text { Nevis }\end{array}$ & 1 \\
\hline Dominica & 1 & Saint Lucia & 1 \\
\hline England & 2 & $\begin{array}{l}\text { St. Vincent \& the } \\
\text { Grenadines }\end{array}$ & 1 \\
\hline Fiji & 11 & Swaziland & 6 \\
\hline Ghana & 29 & Tanzania & 7 \\
\hline Granada & 2 & (The) Bahamas & 1 \\
\hline Guyana & 2 & (The) Gambia & 1 \\
\hline India ( ISET ) & $\begin{array}{l}500 \\
+ \\
\end{array}$ & Tonga & 2 \\
\hline Iran & 6 & Trinadad \& Tobago & 4 \\
\hline Indonesia & 1 & Turkey & 1 \\
\hline Italy & 2 & Tuvalu & 1 \\
\hline Jamaica & 12 & Uganda & 8 \\
\hline Japan & 1 & Venezuela & 1 \\
\hline Kenya & 14 & Vanuatu & 4 \\
\hline Kiribati & 1 & West Indies & 1 \\
\hline Lesotho & 4 & Western Samoa & 1 \\
\hline Malawi & 4 & Zambia & 11 \\
\hline Malaysia & 8 & Zimbabwe & 9 \\
\hline Maldives & 1 & & \\
\hline Malta & 5 & & \\
\hline Mozambique & 4 & Total & $\begin{array}{l}800 \\
+\end{array}$ \\
\hline
\end{tabular}

